\title{
Impact of Organic Fertilizer Produced from Local Substrates on Tomato Growth and
}

Development under Yakutia Conditions

\author{
Daria I. STEPANOVA
}

Ph.D. (in Agricultural Sciences)

Associate Professor

Department of Energy supply in AIC

Yakut State Agricultural Academy

3, Sergelyakhskiy Highway, 3 km, Yakutsk, 677007, Russian Federation

\section{Mikhail F. GRIGOREV}

Ph.D. (in Agricultural Sciences)

Associate Professor

Department of General Zootechnics

Yakut State Agricultural Academy

3, Sergelyakhskiy Highway, 3 km, Yakutsk, 677007, Russian Federation

grig_mf@mail.ru

Alexandra I. GRIGOREVA

Senior Lecturer

Department of Higher Mathematics

North-Eastern Federal University

48, Kulakovskiy Str., Yakutsk, 677013, Russian Federation

\section{Tamara G. DMITRIEVA}

Senior Lecturer

Department of Applied Mechanics

Yakut State Agricultural Academy

3, Sergelyakhskiy Highway, 3 km, Yakutsk, 677007, Russian Fedetarion

$$
7(924) 5980860
$$

\begin{abstract}
This article presents the results of research on the impact of organic fertilizer produced by vermicomposting from local substrates (horse and cattle manure) on the growth and development of tomato seedlings in Yakutia. The basis for these experiments was a very weak supply of vegetable
\end{abstract}


products to settlements, weak accumulation of humus in the natural environment, difficult natural and climatic conditions affecting the efficiency of vegetable production. Experiments were conducted in the greenhouse complex of the pilot production facility "Pokrovskoye" in Khangalassky district of Central Yakutia. A hybrid of the red California worm (Eisenia fetida) was chosen for vermicomposting. Organic fertilizers from different substrates were tested in doses of 10, 30 and 50\% of the soil mix. The application of organic fertilizer produced from horse manure during tomato cultivation had an impact on plant heights. Thus in I and II test groups the maximum height was obtained. Also, the application of organic fertilizer produced from horse manure affected the leaf surface area of plants, the best result was obtained by the II experimental group of plants $291.6 \mathrm{~cm}^{2}$. The application of organic fertilizer produced from cattle manure had a positive impact on the growth and development of tomato plants. In I and II test groups the plants reached the height level of 42-44 cm faster than analogues in other groups. Thus, the use of organic fertilizer from local substrates (farm animal manure) in the norm 10 and $30 \%$ of the total mass of soil contributes to the quality of tomato seedlings.

Keywords: agriculture; fertilization; greenhouse soil mix; protected soil; organic fertilizers; crop production.

\section{Introduction}

The climate of the Republic of Sakha (Yakutia) is sharply continental with sharp seasonal variations in ambient temperature. The average monthly winter temperatures range from $7-8$ to $40-50^{\circ} \mathrm{C}$ below zero. The warmest month of the year is July $-+17-19^{\circ} \mathrm{C}$ (Gavrilova, 1973). The considerable quantity of precipitation falls out in a summer time to $80 \%$ from the annual sum (Bogushevsky, 1974). Spring runoff on frozen soil excludes accumulation by soil for vegetation of plants.

Vermium fertilizers promote rapid restoration of reusable soil and stimulate growth and productivity of plants (Arjune et al., 2019; Kumar et al., 2018; Liu et al., 2019). According to scientists from Italy, humus substances contained in vermicompost are similar to those present in soils (Melnik, Slavgorodskaya, 2013; Tomati et al., 1987). The organic mass processed by worms increases humification factor up to 2 times (Barthod et al., 2018; Wu et al., 2019). Commercial production of biohumus has been established in countries such as the United Kingdom, the Netherlands, Germany, Poland, Hungary, the Philippines, South America and Australia (Aracon et al., 2004; Stepanov, 2016).

When studying vermicompost from different raw materials, there are no significant differences between the chemical parameters of the greenhouse soil when applying the same doses of substrates 
and vermicompost. Both types of fertilizers increased the content of organic matter, total nitrogen, and available nitrogen, phosphorus, and potassium compounds relative to the control variant. When applying the initial substrate and vermicompost in the steam soil, higher electrical conductivity and lower concentrations of mobile phosphorus and organic matter were observed compared to the soil under plants. Three-year tests of vermicompost when growing greenhouse vegetables showed that the yield of cucumber in relation to wind control increased to $27 \%$, and the yield of tomato to $29 \%$. At the same time, low doses of vermicompost were more effective for both cultures. Increasing the doses of fertilizer over did not give a significant positive effect. The introduction of vermicompost did not affect the quality of fruits in terms of such indicators as the content of nitrates and vitamin C. When growing vegetables with increasing doses of vermicompost in the fruit slightly increased the content of dry matter, sugars and vitamin C. However, with the subsequent increase in doses of vermicompost, there was a decrease in the content of these quality indicators. The content of nitrates in tomatoes increased sharply when the maximum dose of fertilizer was applied. In General, the quality of vegetable products was quite high and met the hygienic requirements. When growing tomatoes in greenhouses, much attention is paid to the quality of seedlings. Researches of scientists have established that vermiculture promotes intensive growth, development and productivity of vegetable crops, improving the immunity of the plant (Feng et al., 2018; Gill et al., 2018; Pathma et al., 2019; Sharma, Garg, 2019).

Literature analysis shows that the quality of seedlings is positively affected by the use of vermicompost, which ultimately contributes to an increase in the early and overall yield of vegetable products. This became the basis for conducting similar studies, but using local substrates in the specific climate of Central Yakutia.

To date, effective methods of vermicomposting of organic waste from animal husbandry and their use in the system of growing vegetables in Yakutia have not been sufficiently developed.

Purpose of research is to study the effects of the efficiency of organic fertilizer (vermicompost) created from local raw materials in the cultivation of tomatoes in Yakutia.

\section{Objectives of research are:}

- Studying the effect of alley apple vermicompost on tomato growth and development;

- Studying the impact of cattle dung vermicompost on tomato growth and development.

\section{Methods}

Scientific experiments to study the efficiency of various organic fertilizers (vermicompost from local substrates - manure and cattle dung and alley apple) in growing Verliok hybrid tomatoes are 
organized on the basis of the greenhouse complex of pilot production farm "Pokrovskoe" Khangalassky district of Central Yakutia. For vermicomposting, a hybrid of the red California worm (Eisenia fetida) was chosen.

The scientific experience in studying the influence of vermicompost from different local substrates in growing tomato seedlings included the following groups: control group - seedlings mixture; I pilot group - seedlings mixture $+10 \%$ vermicompost; II pilot group - seedlings mixture $+30 \%$ vermicompost; III pilot group - seedlings mixture $+50 \%$ vermicompost. Repetition of the experience is three times.

The composition of seedling soil: 40\% - turf, 30\% - overlapping manure and 30\% - sawdust. Seedlings were grown at a temperature of $+20^{\circ} \mathrm{C}$. Sowing was carried out on March 20. The height of plants and area of leaf surface were measured.

In the experience, the pre-sowing preparation of tomato seeds was carried out taking into account their calibration with $5 \%$ solution of table salt; and disinfection within 3 days was carried out by heating in a thermostat at a temperature of $+50-52^{\circ} \mathrm{C}$, wetting for 12 hours and germination in a wet cloth. The germinated seeds were kept in the refrigerator for $3-5$ days at $0-3^{\circ} \mathrm{C}$ temperature mode. The tomato was sown in the 3rd decade of March. The greenhouse soil consisted in proportions of $40 \%$ of turf, $30 \%$ of overpignose and $30 \%$ of sawdust, in experimental groups was added biofertilizer (vermicompost) from 10 to $50 \%$.

During the experiments, all plants of all experimental groups were not exposed to diseases and gave sufficient yield within a short period of vegetation.

\section{Results}

Experimental seedlings at the age of 70 days with 9-10 developed sheets were planted on a permanent place in the greenhouse (according to the scheme of experience). Biofertilizer based on horse manure had a mixed effect on the growth rates of seedlings of experimental groups of plants (Table 1 and Table 2).

Table 1. Impact of different biofertilizer doses (worm manure based on alley apple) on seedlings height indices, cm

\begin{tabular}{|c|c|c|c|c|c|c|c|}
\hline Groups & Years & $3^{\mathrm{d}}$ and $4^{\text {th }}$ leaves & $5^{\text {th }}$ leaf & $6^{\text {th }}$ leaf & $7^{\text {th }}$ leaf & $8^{\text {th }}$ leaf & $\begin{array}{l}10-11^{\text {th }} \\
\text { leaves }\end{array}$ \\
\hline \multirow{4}{*}{$\begin{array}{l}\text { Control group } \\
\text { (grass-grown potting soil } \\
\text { mixture) }\end{array}$} & $1^{\text {st }}$ year & 7.8 & 11.4 & 15.7 & 18.5 & 35.0 & 42.7 \\
\hline & $2^{\text {nd }}$ year & 10.7 & 13.3 & 24.6 & 29.7 & 26.7 & 64.3 \\
\hline & $3^{\text {rd }}$ year & 8.3 & 12.5 & 18.9 & 21.3 & 28.1 & 48.5 \\
\hline & 3-year average & 8.9 & 12.4 & 19.7 & 23.2 & 29.9 & 51.8 \\
\hline \multirow{2}{*}{$\begin{array}{l}\text { I test group (grass-grown } \\
\text { potting soil mixture + }\end{array}$} & $1^{\text {st }}$ year & 8.2 & 12.6 & 16.4 & 18.7 & 22.8 & 47.9 \\
\hline & $2^{\text {nd }}$ year & 12.2 & 16.0 & 35.2 & 43.3 & 47.4 & 72.2 \\
\hline
\end{tabular}




\begin{tabular}{|c|c|c|c|c|c|c|c|}
\hline \multirow[t]{2}{*}{$10 \%$ of worm manure) } & $3^{\text {rd }}$ year & 10.5 & 15.9 & 23.5 & 28.8 & 32.0 & 53.6 \\
\hline & 3-year average & 10.3 & 14.8 & 25.0 & 30.3 & 34.1 & 57.9 \\
\hline \multirow{4}{*}{$\begin{array}{l}\text { II test group (grass-grown } \\
\text { potting soil mixture }+ \\
30 \% \text { of worm manure) }\end{array}$} & $1^{\text {st }}$ year & 9.7 & 13.5 & 17.3 & 19.8 & 23.2 & 48.2 \\
\hline & $2^{\text {nd }}$ year & 12.7 & 15.2 & 35.8 & 43.8 & 47.1 & 72.0 \\
\hline & $3^{\text {rd }}$ year & 10.5 & 14.7 & 31.6 & 34.2 & 38.6 & 63.6 \\
\hline & 3-year average & 10.9 & 14.5 & 28.2 & 32.6 & 36.3 & 61.3 \\
\hline \multirow{4}{*}{$\begin{array}{l}\text { III test group (grass- } \\
\text { grown potting soil mixture } \\
+50 \% \text { of worm manure) }\end{array}$} & $1^{\text {st }}$ year & 8.7 & 11.5 & 15.9 & 19.2 & 23.0 & 48.0 \\
\hline & $2^{\text {nd }}$ year & 12.4 & 14.8 & 36.7 & 40.9 & 44.0 & 69.4 \\
\hline & $3^{\text {rd }}$ year & 9.2 & 12.3 & 29.5 & 33.2 & 37.2 & 62.9 \\
\hline & 3 -year average & 10.1 & 12.9 & 27.4 & 31.1 & 34.7 & 60.1 \\
\hline
\end{tabular}

It was found that when biofertilizer (produced from horse manure) was applied to the soil substrate, it had a positive effect on the height of the seedling. So the maximum growth was obtained in I and II experimental groups in greenhouse soil was added vermicompost in the calculation of 100 and $300 \mathrm{~g}$ per $1 \mathrm{~kg}$ of soil mixture.

Table 2. Impact of organic fertilizer (worm manure based on alley apple) on photosynthetic plant apparatus during seed period, $\mathrm{cm}^{2}$

\begin{tabular}{|c|c|c|c|c|c|}
\hline Groups & Years & $\begin{array}{l}3^{\text {rd }} \text { and } 4^{\text {th }} \\
\text { leaves }\end{array}$ & $6-7^{\text {th }}$ leaves & $8-9^{\text {th }}$ leaves & $\begin{array}{l}10-11^{\text {th }} \\
\text { leaves }\end{array}$ \\
\hline \multirow{2}{*}{$\begin{array}{l}\text { Control group } \\
\text { (grass-grown }\end{array}$} & $1^{\text {st }}$ year & 13.8 & 93.7 & 126.9 & 228.1 \\
\hline & $2^{\text {nd }}$ year & 7.6 & 67 & 101.7 & 203.0 \\
\hline \multirow{2}{*}{$\begin{array}{l}\text { potting } \\
\text { mixture) }\end{array}$} & $3^{\text {rd }}$ year & 6.9 & 43.5 & 72.4 & 172.7 \\
\hline & 3 year average & 9.4 & 68.1 & 100.3 & 201.3 \\
\hline \multirow{4}{*}{$\begin{array}{l}\text { I test group (grass- } \\
\text { grown potting soil } \\
\text { mixture }+10 \% \text { of } \\
\text { worm manure) }\end{array}$} & $1^{\text {st }}$ year & 8.9 & 178.8 & 192.6 & 272.4 \\
\hline & $2^{\text {nd }}$ year & 9.4 & 212.3 & 226.7 & 317.5 \\
\hline & $3^{\text {rd }}$ year & 8.5 & 155.6 & 167.4 & 228.5 \\
\hline & 3 year average & 8.9 & 182.3 & 195.6 & 270.8 \\
\hline \multirow{4}{*}{$\begin{array}{l}\text { II test group } \\
\text { (grass-grown } \\
\text { potting soil } \\
\text { mixture }+30 \% \text { of } \\
\text { worm manure) } \\
\end{array}$} & $1^{\text {st }}$ year & 9.0 & 121.4 & 212.4 & 302.3 \\
\hline & $2^{\text {nd }}$ year & 9.4 & 125.3 & 216.5 & 306.8 \\
\hline & $3^{\text {rd }}$ year & 8.5 & 104.7 & 175.6 & 265.6 \\
\hline & 3 year average & 9.0 & 117.1 & 201.5 & 291.6 \\
\hline \multirow{4}{*}{$\begin{array}{l}\text { III test group } \\
\text { (grass-grown } \\
\text { potting soil } \\
\text { mixture }+50 \% \text { of } \\
\text { worm manure) }\end{array}$} & $1^{\text {st }}$ year & 8.9 & 109.8 & 154.6 & 284.2 \\
\hline & $2^{\text {nd }}$ year & 9.1 & 161.7 & 221.7 & 299.0 \\
\hline & $3^{\text {rd }}$ year & 8.3 & 117.4 & 167.4 & 238.6 \\
\hline & 3 year average & 9.0 & 129.6 & 181.2 & 273.9 \\
\hline
\end{tabular}

Measurements of the photosynthetic apparatus of tomatoes found that in the control group at the time of formation of 9-11 leaves, their area was 100-201 $\mathrm{cm}^{2}$. In the II experimental group where biofertilizer was used the best result was obtained - the area of leaves $-291.6 \mathrm{~cm}^{2}$.

The influence of biofertilizer (vermicompost based on cattle manure) on tomato seedling growth indicators was also determined, the data are presented in Table 3.

Table 3. Impact of organic fertilizer (worm manure based on cattle dung) on plants height indices during seed period, $\mathrm{cm}$

\begin{tabular}{|c|c|c|c|c|c|c|}
\hline Groups & Years & $5^{\text {th }}$ leaf & $6^{\text {th }}$ leaf & $7^{\text {th }}$ leaf & $8^{\text {th }}$ leaf & $9^{\text {th }}$ leaf \\
\hline Control & $1^{\text {st }}$ year & 14.7 & 23.0 & 27.4 & 34.5 & 37.9 \\
\hline (grass-grown & $2^{\text {nd }}$ year & 13.3 & 24.3 & 29.3 & 33.0 & 37.0 \\
\hline
\end{tabular}




\begin{tabular}{|c|c|c|c|c|c|c|}
\hline \multirow[t]{2}{*}{ potting soil mixture) } & $3^{\text {rd }}$ year & 15.2 & 25.2 & 28.5 & 29.7 & 36.7 \\
\hline & 3 year average & 14.4 & 24.2 & 28.4 & 32.4 & 37.2 \\
\hline \multirow{4}{*}{$\begin{array}{l}\text { I test group (grass- } \\
\text { grown potting soil } \\
\text { mixture }+10 \% \text { of } \\
\text { worm manure) }\end{array}$} & $1^{\text {st }}$ year & 15.0 & 26.3 & 32.5 & 36.2 & 43.8 \\
\hline & $2^{\text {nd }}$ year & 15.0 & 26.7 & 39.3 & 35.0 & 41.0 \\
\hline & $3^{\text {rd }}$ year & 18.2 & 26.8 & 31.0 & 35.7 & 41.7 \\
\hline & 3 year average & 16.1 & 26.6 & 30.9 & 35.9 & 42.2 \\
\hline \multirow{4}{*}{$\begin{array}{l}\text { II test group (grass- } \\
\text { grown potting soil } \\
\text { mixture }+30 \% \text { of } \\
\text { worm manure) }\end{array}$} & $1^{\text {st }}$ year & 16.0 & 27.4 & 32.9 & 37.2 & 42.1 \\
\hline & $2^{\text {nd }}$ year & 18.0 & 29.0 & 30.0 & 37.0 & 46.3 \\
\hline & $3^{\text {rd }}$ year & 15.5 & 29.2 & 29.3 & 35.8 & 44.3 \\
\hline & 3 year average & 16.5 & 28.5 & 30.7 & 36.7 & 44.2 \\
\hline \multirow{4}{*}{$\begin{array}{l}\text { III test group (grass- } \\
\text { grown potting soil } \\
\text { mixture }+50 \% \text { of } \\
\text { worm manure) }\end{array}$} & $1^{\text {st }}$ year & 17.3 & 25.5 & 28.9 & 33.8 & 44.3 \\
\hline & $2^{\text {nd }}$ year & 17.0 & 27.7 & 30.0 & 40.7 & 35.0 \\
\hline & $3^{\text {rd }}$ year & 14.3 & 27.0 & 28.2 & 36.0 & 43.0 \\
\hline & 3 year average & 16.2 & 26.7 & 29.0 & 34.9 & 42.7 \\
\hline
\end{tabular}

On average, during 3 years of research, plants from I and II experimental groups reached the height of $42-44 \mathrm{~cm}$ faster, their average stem diameter was 0.6-0.7 cm.

When studying the formation of the photosynthetic apparatus of tomatoes in the seedling period, positive results of the biofertilizer effect were obtained (Table 4).

Table 4. Behavior pattern of organic fertilizer impact (worm manure based on cattle dung) on photosynthetic plant apparatus during seed period, $\mathbf{c m}^{2}$

\begin{tabular}{|c|c|c|c|c|c|c|}
\hline \multirow{2}{*}{ Groups } & \multirow{2}{*}{ Years } & \multicolumn{5}{|c|}{ Stage of plant development } \\
\hline & & $5^{\text {th }}$ leaf & $6^{\text {th }}$ leaf & $7^{\text {th }}$ leaf & $8^{\text {th }}$ leaf & $9^{\text {th }}$ leaf \\
\hline \multirow{4}{*}{$\begin{array}{l}\text { Control group (grass- } \\
\text { grown potting soil } \\
\text { mixture) }\end{array}$} & $1^{\text {st }}$ year & 65.3 & 137.9 & 143.2 & 167.6 & 196.5 \\
\hline & $2^{\text {nd }}$ year & 59.2 & 155.9 & 202.7 & 226.0 & 241.3 \\
\hline & $3^{\text {rd }}$ year & 72.6 & 144.0 & 150.0 & 215.7 & 212.4 \\
\hline & 3 year average & 65.7 & 145.9 & 165.3 & 203.1 & 216.7 \\
\hline \multirow{4}{*}{$\begin{array}{l}\text { I test group (grass- } \\
\text { grown potting soil } \\
\text { mixture }+10 \% \text { of } \\
\text { worm manure) }\end{array}$} & $1^{\text {st }}$ year & 104.1 & 160.9 & 178.8 & 228.8 & 287.1 \\
\hline & $2^{\text {nd }}$ year & 66.3 & 171.3 & 206.7 & 252.3 & 328.0 \\
\hline & $3^{\text {rd }}$ year & 102.0 & 157.3 & 215.7 & 273.7 & 312.3 \\
\hline & 3 year average & 90.8 & 163.2 & 200.4 & 251.6 & 309.0 \\
\hline \multirow{4}{*}{$\begin{array}{l}\text { II test group (grass- } \\
\text { grown potting soil } \\
\text { mixture }+30 \% \text { of } \\
\text { worm manure) }\end{array}$} & $1^{\text {st }}$ year & 66.7 & 214.0 & 259.8 & 300.5 & 354.3 \\
\hline & $2^{\text {nd }}$ year & 66.0 & 225.3 & 260.7 & 314.0 & 406.0 \\
\hline & $3^{\text {rd }}$ year & 74.3 & 208.3 & 232.3 & 397.0 & 370.0 \\
\hline & 3 year average & 64.0 & 215.9 & 250.9 & 303.8 & 377.0 \\
\hline \multirow{4}{*}{$\begin{array}{l}\text { III test group } \\
\text { (grass-grown potting } \\
\text { soil mixture }+50 \% \text { of } \\
\text { worm manure) }\end{array}$} & $1^{\text {st }}$ year & 58.2 & 163.5 & 223.5 & 296.4 & 351.8 \\
\hline & $2^{\text {nd }}$ year & 65.0 & 159.0 & 230.7 & 210.4 & 371.0 \\
\hline & $3^{\text {rd }}$ year & 68.0 & 164.3 & 229.7 & 285.0 & 349.3 \\
\hline & 3 year average & 63.7 & 162.3 & 227.9 & 297.2 & 357.4 \\
\hline
\end{tabular}

\section{Discussion}

A certain influence of biofertilizer (vermicompost based on cattle manure) on the leaf surface area of plants has been established. At the same time the best result was obtained by I and II experimental groups. It should be noted that in the III experimental group, where biofertilizer in a dose of $50 \%$ of greenhouse soil mixture was used, a decrease in the studied indicators was observed. 


\section{Conclusion}

The use of biofertilizer in the cultivation of tomato seedlings has shown better results with low rates of their application to the soil. The positive effect on photosynthetic apparatus and tomato seedling growth was established. When comparing the results of biofertilizer efficiency from different local substrates (vermicompost of cattle and horse manure) the optimal norms of their application into the soil mixture were determined and made up 10 and $30 \%$.

In the III pilot group, where biofertilizer accounted for $50 \%$ of plant depression and a decrease in biometric growth rates. When comparing the low dose $(10 \%)$ and average dose $(30 \%)$, where the maximum biometric indicators were obtained in the experimental groups of plants, preference is given to low rates. In this option, the maximum economic efficiency in terms of production costs, reducing the time of growing seedlings on 14 days.

The use of biofertilizer in plant cultivation contributed to obtaining seedlings with strong root system and large flower brushes with a height of $40-50 \mathrm{~cm}$. Vermicompost fertilization was carried out 4 times during vegetation.

Introduction of biofertilizer into soil promoted intensive growth and development of tomato seedlings. At the same time the best variant was possessed by experimental groups, where biofertilizer application made $10-30 \%$ of the soil mixture. The best result in height of plants was 34$36 \mathrm{~cm}$, and the area of photosynthetic apparatus $-195-201 \mathrm{~cm}^{2}$.

Thus, biofertilizer application from local substrates from 10-30\% of the total mass of the soil mixture contributed to obtaining high-quality tomato seedlings.

\section{References}

Aracon, N.Q., Edwards, C.A., Atiyeh, R.M., Metzger, J.D. (2004). Effects of vermicomposts produced from food waste on the growth and yelds of greenhouse peppers. Bioresource Technology, 93(2), 139-144. DOI: 10.1016/j.biortech.2003.10.015

Arjune, Y.P., Ansari, A.A., Jaikishun, S., Homenauth, O. (2019). Effect of vermicompost and other fertilizers on soil microbial population and growth parameters of f1 mongal tomato (Solanum lycopersicum mill.). Pakistan Journal of Botany, 51(5), 1883-1889. DOI: 10.30848/PJB2019-5(1)

Barthod, J., Rumpel, C., Calabi-Floody, M., Mora, M.L., Bolan, N.S., Dignac, M.F. (2018). Adding worms during composting of organic waste with red mud and fly ash reduces $\mathrm{CO} 2$ emissions and increases plant available nutrient contents. Journal of environmental management, 222, 207-215. DOI: 10.1016/j.jenvman.2018.05.079 
IV International Scientific and Practical Conference "Modern S\&T Equipments and Problems in Agriculture"

Bogushevsky, A.A. (1974). Land reclamation in the permafrost zone. Moscow: Kolossus.

Feng, T., Huang, H., Chen, F., Fan, J., Wei, M. (2018). Effects of different application amounts of vermicompost on agronomic trait, yield and quality of continuous cropping cucumber. Journal of Southern Agriculture, 49(8), 1575-1580.

Gavrilova, M.K. (1973). The climate of central Yakutia. Yakutsk: Yakut book publishing house.

Gill, P., Singh, D., Kumar, T.R., Kumar, P., Gupta, R.K. (2018). Comparative Effect of Different Fertilizers on Various Growth Parameters of Lycopersicum esculantum. International Journal of Current Microbiology and Applied Sciences, 7(1), 56-60. DOI: $10.20546 / \mathrm{ijcmas} .2018 .701 .008$

Kumar, A., Prakash, C.H., Brar, N.S., Kumar, B. (2018). Potential of vermicompost for sustainable crop production and soil health improvement in different cropping systems. International Journal of Current Microbiology and Applied Sciences, 7(10), 1042-1055. DOI: $10.20546 / \mathrm{ijcmas.2018.710.116}$

Liu, M., Wang, C., Wang, F., Xie, Y. (2019). Vermicompost and humic fertilizer improve coastal saline soil by regulating soil aggregates and the bacterial community. Archives of Agronomy and Soil Science, 65(3), 281-293. DOI: 10.1080/03650340.2018.1498083

Melnik, O.A., Slavgorodskaya, D.A. (2013). The effect of complex compost on the physical properties of common chernozem and the problem of soil protection in the agrolandscape system. Ecological Bulletin of the North Caucasus, 9(3), 5-81.

Pathma, J., Raman, G., Sakthivel, N. (2019). Microbiome of Rhizospheric Soil and Vermicompost and Their Applications in Soil Fertility, Pest and Pathogen Management for Sustainable Agriculture. Soil Fertility Management for Sustainable Development. Springer, Singapore, 189-210. DOI: 10.1007/978-981-13-5904-0_9

Sharma, K., Garg, V.K. (2019). Vermicomposting of Waste: A Zero-Waste Approach for Waste Management. Sustainable Resource Recovery and Zero Waste Approaches. Elsevier, 133-164. DOI: 10.1016/B978-0-444-64200-4.00010-4

Stepanov, A.I. (2016). Agroecological fundamentals of the production and use of organic fertilizers on permafrost soils of Yakutia. A dissertation for the degree of Doctor of Agricultural Sciences. All-Russian Research Institute of Agrochemistry named after D.N. Pryanishnikova. Moscow. 
IV International Scientific and Practical Conference "Modern S\&T Equipments and Problems in Agriculture"

Tomati, U., Galli, E., Grapelli, A. (1987). Vermicompost, after its inclusion in the official table of law 748/8. L'informatore Agrario, 43(30), 51-54.

Wu, Z., Yin, B., Song, X., Zhao, Q. (2019). Effects of different lipid contents on growth of earthworms and the products during vermicomposting. Waste Management \& Research, 37(9), 934-940. DOI: 10.1177/0734242X19861683 